\title{
Strategy Management Using SWOT Analysis on Patient Satisfaction Rate in Dr. Sardjito Central General Hospital
}

\author{
Rochana Ruliyandari* \\ *M Author Correspondence: rochanaruli.fkmuad@gmail.com \\ * Department of Hospital Management, Faculty of Public Health, Universitas Ahmad Dahlan, Indonesia

\begin{tabular}{lll}
\hline I N D E X I N G & A B S T R AC T \\
\cline { 1 - 3 } Keywords: & Dr. Sardjito Central General Hospital is a class A teaching hospital which is a DIY and South Central \\
Patient Satisfaction; & Java referral hospital. This hospital still has a disadvantage in terms of patient satisfaction, where it \\
Strategy Management & has not met the standards set by national standards $\geq 85 \%$ and the target of medium-term hospitals in \\
& 2017 is $90 \%$ but the achievement of Dr Sardjito General Hospital is $81.66 \%$. Deficiencies in terms of \\
& these services can be a weakness and even a threat to Dr. Sardjito General Hospital. Therefore, to \\
analyze these problems using a strategy using the SWOT analysis method. The method used is \\
descriptive. The type of data used secondary data, namely from records or company documentation \\
and scientific publications. Obtained a total FSI score of 3.35 means greater strength than weakness. \\
The total FSE score of 3.65 means that the opportunity was greater than the threat. The strategy that \\
can be used based on the SWOT analysis is strength and opportunity.
\end{tabular}

Kata kunci:

Analisis SWOT;

Kepuasan Pasien;

Manajemen Strategi

\begin{abstract}
Rumah Sakit Umum Pusat Dr Sardjito merupakan rumah sakit pendidikan kelas A yang menjadi rumah sakit rujukan DIY dan Jawa Tengah Selatan. Rumah Sakit ini masih memiliki kekurangan salah satunya dari segi kepuasan pasien, dimana belum memenuhi standar yang telah ditetapkan oleh standar nasional $\geq 85 \%$ dan target jangka menengah rumah sakit tahun 2017 adalah $90 \%$ tetapi pencapaian RSUP Dr Sardjito adalah 81,66\%. Kekurangan dalam hal pelayanan tersebut dapat menjadi kelemahan bahkan ancaman bagi RSUP Dr Sardjito. Oleh karena itu, untuk menganalisis permasalahan tersebut menggunakan strategi dengan metode analisis SWOT. Metode yang digunakan adalah deskriptif. Jenis data menggunakan data sekunder yaitu dari catatan atau dokumentasi perusahaan dan publikasi ilmiah. Didapatkan total skor FSI sebesar 3,35 artinya kekuatan lebih besar dari kelemahan. Total skor FSE sebesar 3,65 artinya peluang lebih besar dari ancaman. Strategi yang dapat digunakan berdasarkan analisis SWOT adalah kekuatan dan peluang.
\end{abstract}

(C) 2019 JMMR. All rights reserved

Article History: Received 2019-Apr-01; Revised 2019-Jun-27; Accepted 2019-Aug-09

\section{INTRODUCTION}

Every company should be able to make a proper marketing strategy and can make a plan to be able to compete in the present and future. Companies engaged in the marketing of services also needed a strategy to increase competitiveness among similar companies..$^{-}$The business is not easy because the company should have the right competitive strategy in achieving a competitive advantage. This aims to realize customer satisfaction with the products/services offered by a company.

Along with rapid technological developments and increasing socio-economic conditions in the community, will trigger demands for increased health services. Competition between agencies also increases with the number of private hospitals currently. This competition is certainly not only from the technology side of the hospital, but also quality health services that will be sought by the public. ${ }^{-}$
Patient satisfaction is the most important part of the quality of health. Health quality is often measured by its traditional structure, process and results which includes stages as morbidity, mortality, and functional improvement. ${ }^{-}$Therefore, patient satisfaction is also part of this dimension. The dimensions of the quality of health services are specific contexts and patients provide diverse opinions. The construct of the quality of health care and its measurement is mainly carried out from a patient perspective, but the service provider's perspective on the quality of health services has not been considered..$^{5}$

Customer satisfaction as a patient in a health service can be influenced by various factors. Customer satisfaction in the hospital or the patient is also influenced by good health care, promotion, physical evidence, process, and personal strategies. ${ }^{6}$ Health services that influence patient satisfaction are shown in Rosalia and Purnawati's research at Surya Husadha General Hospital Denpasar. Patient 
satisfaction is influenced by physical evidence, reliability, assurance, and empathy variables. ${ }^{-}$This is also in line with the results of research by Rensiner that reliability, responsiveness, confidence, empathy, and physical evidence influence patient satisfaction in the outpatient clinic at RSUD Dr. Achmad Darwis..$^{-}$Health services in hospitals are now required to serve patients quickly, accurately, quality, and affordable so as to provide satisfaction to patients regarding the results of care. ${ }^{-}$

The changing situation of the times can make the opportunity to increase business or even become a threat to the company. One effort to find out the right strategy for the company is with a SWOT analysis. ${ }^{10}$ SWOT analysis is a systematic identification of various factors to formulate a company's strategy. Generally, determining the right strategy for the company began to recognize the opportunity and threats contained in the external environment as well as to understand the strength and weakness on the internal aspects of the company. Thus, companies are able to compete and achieve goals effectively and efficiently. ${ }^{10}$

Dr Sardjito General Hospital is a Class A Teaching Hospital which is a DIY and South Central Java referral hospital. This hospital still lacks one of them in terms of patient satisfaction. The standard set by national standards is $\geq 85 \%$ and the target for hospital mid-term in 2017 is
$90 \%$ but the achievement of Dr. Sardjito General Hospital is $81.66 \% .^{11}$ Deficiencies in terms of these services can be a weakness and even a threat to Dr. Sardjito General Hospital. Therefore, to analyze these problems using a strategy using the SWOT analysis method.

\section{RESEARCH METHOD}

The type of method used is descriptive. This study used SWOT analysis to analyze the problem. The data used secondary data that refers to information collected from existing sources. Secondary data sources used are obtained from company records or documents, internet sites, government publications, industry analysis by the media, previous research can be in the form of scientific journals or theses, and other reading related to this research. ${ }^{12}$

\section{RESULT AND DISCUSSION}

Quality of service is measured by the gap between the perceived real service expected of patients with patient care. The resulting gap value is assumed to be the value of the quality of services provided by the various installations in Dr. Sardjito General Hospital to patients that will affect the patient satisfaction rate. The results of the gap analysis obtained at Dr. Sardjito General Hospital can be seen in solid Table 1.

Table1. Results of the Analysis of Patient Satisfaction Figures at Dr. Sardjito Hospital in 2017

\begin{tabular}{lllll}
\hline Target Activities & Performance Indicators & Standard & 2016 Realization & 2017 Realization \\
& & & & \\
\hline Realization of Stakeholder Satisfaction & Patient Satisfaction Rate & $\geq 85 \%$ & $81,66 \%$ & $81,66 \%$
\end{tabular}

\section{Strength}

Strength is an advantage in other resources, skills and abilities relative to competitors and the market needs that are served by the company. For example, in terms of technology owned and owned facilities. The strength possessed by Dr. Sardjito General Hospital includes: 1) Resources in the form of a large number of health workers and are competent and friendly officers; 2) Facilities and infrastructure including a strategic location in the middle of the city and can be passed by public transportation, have complete medical equipment, complete supporting facilities, and clean canteen.

The severity of the disease suffered by patients, health care managers still have to improve nursing care and care staff, so that patient satisfaction increases significantly. ${ }^{-13}$ Another study found that the competence of employees and hospital facilities significantly influence patient satisfaction Grade 3 Undata Palu Hospital. ${ }^{14}$ Another study by Safitri stated that service quality, location, and rates affected the inpatient satisfaction of Lestari Raharja Magelang Hospital. $\frac{15}{}$

\section{Weakness}

This weakness can also be in the form of resources, skills and abilities that seriously hinder the effective performance of a company. For example, employee skill levels and small promotion costs. The weaknesses possessed by Dr. Sardjito General Hospital include: 1) There are still a lot of unproductive labor resources due to inappropriate placement which results in workloads for employees and lack of coordination between officers; 2) Facilities and infrastructure including parking spaces are 
less extensive (narrow), congested access when morning, and small prayer rooms.

Placement of employees who are not in accordance with the ability will affect the performance of employees. This was in accordance with other studies which state that the suitability of ability had a significant effect on employee placement. ${ }^{16}$ Therefore, a poor employee performance can make patient satisfaction decreases.

A less extensive parking area affects patient satisfaction. In accordance with other studies stating that location had a positive effect on patient satisfaction. ${ }^{15}$ Considerations for choosing a location can be access, visibility, parking, skit environment, traffic, expansion, competition, and government regulation. ${ }^{17}$

\section{Opportunity}

Opportunities are the main favorable situation in the corporate environment, for example government policies and relatively high economic growth rates. The opportunities possessed by Dr. Sardjito General Hospital include: 1) The location of this hospital is strategic, so that not only local residents can reach but also tourists from outside; 2) Quality of service is trusted; 3) As a teaching hospital that always accepts student practice not only from Gadjah Mada University (UGM).

Haryanto's research stated that the quality of medical personnel and the quality of hospital services make patients go back to treatment. $\frac{18}{}$ This supports the opportunity of Dr. Sardjito General Hospital to attract patients to return to treatment. Therefore, hospitals must improve the quality of their employees and services.

\section{Threat}

Threats are the main unfavorable situation in a company's environment. For example, the rapid competition of healthcare providers. The threats possessed by Dr. Sardjito General Hospital include: 1) The existence of public perceptions related to expensive service costs; 2) Close to the highway so that it is vulnerable to air pollution;

3) Because many patients are prone to nosocomial infections.

The success of product marketing and the survival of the company is determined by the price/tariff imposed by a company. Consumer perception of the cost of care has an effect on patient satisfaction. This statement is in accordance with research by Kusuma at RAA Soewondo Hospital Pati. ${ }^{19}$ This will certainly be a threat to Dr. Sardjito General Hospital related to service rates.

\section{Decision Making}

The level of interest in the internal environment of the weighting is based on the influence of strategic factors, while the external environment is based on the possibility of an impact on the strategic factor. .10 The SWOT matrix interacts with internal and external strategic factors, namely by describing how the opportunities and threats faced can be adapted to existing strengths and weaknesses. The results of this matrix will produce a strategic alternative that can be done. ${ }^{20}$

The IFAS score in Table 2 is 2.00 , indicating that strength $(\mathrm{S})$ is greater than weakness $(\mathrm{W})$, which means that the strength possessed by Dr. Sardjito General Hospital is more prominent than its weaknesses, so the strategy taken is strength and opportunity (SO). The EFAS score in Table 3 is 2.00 , indicating that opportunity $(\mathrm{O})$ is greater than threat ( $\mathrm{T}$ ), which means that the threat possessed by RSUP Dr. Sardjito is covered by the opportunities it has. The results of IFAS and EFAS scores have a value $>2.00$, so the strategies that can be chosen are strength and opportunity (SO), using the power to seize aggressive opportunities, expansion, growth oriented strategy. The SO strategy is carried out by optimizing the power possessed to take advantage of existing opportunities..$^{-0}$

Table 2. Data Analysis (Internal Factor Aanalysis Strategy Matrix)

\begin{tabular}{|c|c|c|c|c|}
\hline No. & Internal Strategic Factor & Weight & Rate & Score \\
\hline & Strengths & & & \\
\hline \multirow[t]{4}{*}{1.} & Resources & & & \\
\hline & Health personnel sufficient, competent and friendly & 0.10 & 3 & 0.30 \\
\hline & Specialist and sub-specialist medical personnel are available & 0.025 & 4 & 0.10 \\
\hline & There are many patients & 0.025 & 3 & 0.075 \\
\hline \multirow[t]{4}{*}{2.} & Infrastructure & & & \\
\hline & Strategic location & 0.10 & 3 & 0.30 \\
\hline & Strong promotion & 0.025 & 2 & 0.05 \\
\hline & Has complete medical equipment and supporting facilities & 0.10 & 3 & 0.30 \\
\hline
\end{tabular}


Table 2. (continued) Data Analysis (Internal Factor Aanalysis Strategy Matrix)

\begin{tabular}{|c|c|c|c|c|}
\hline No. & Internal Strategic Factor & Weight & Rate & Score \\
\hline 3. & Referral service center & 0.025 & 2 & 0.05 \\
\hline 4. & Primary teaching hospital & 0.10 & 3 & 0.30 \\
\hline 5. & National health service accredited & 0.15 & 4 & 0.60 \\
\hline 6. & $\begin{array}{l}\text { Good coordination and communication with the Faculty of Medicine, Gadjah } \\
\text { Mada University }\end{array}$ & 0.15 & 4 & 0.60 \\
\hline \multicolumn{5}{|c|}{ Weaknesses } \\
\hline \multirow[t]{3}{*}{1.} & Resources & & & \\
\hline & $\begin{array}{l}\text { There are still a lot of unproductive workers because of inappropriate } \\
\text { placement that results in workloads for employees }\end{array}$ & 0.10 & 4 & 0.40 \\
\hline & Lack of coordination among officers & 0.05 & 3 & 0.15 \\
\hline \multirow[t]{3}{*}{2.} & Infrastructure & & & \\
\hline & Narrow Parking Area & 0.025 & 2 & 0.05 \\
\hline & Small mushola & 0.025 & 3 & 0.075 \\
\hline Total & & & 3.35 & \\
\hline
\end{tabular}

Table 3. Data Analysis (External Factor Analysis Strategy Matrix)

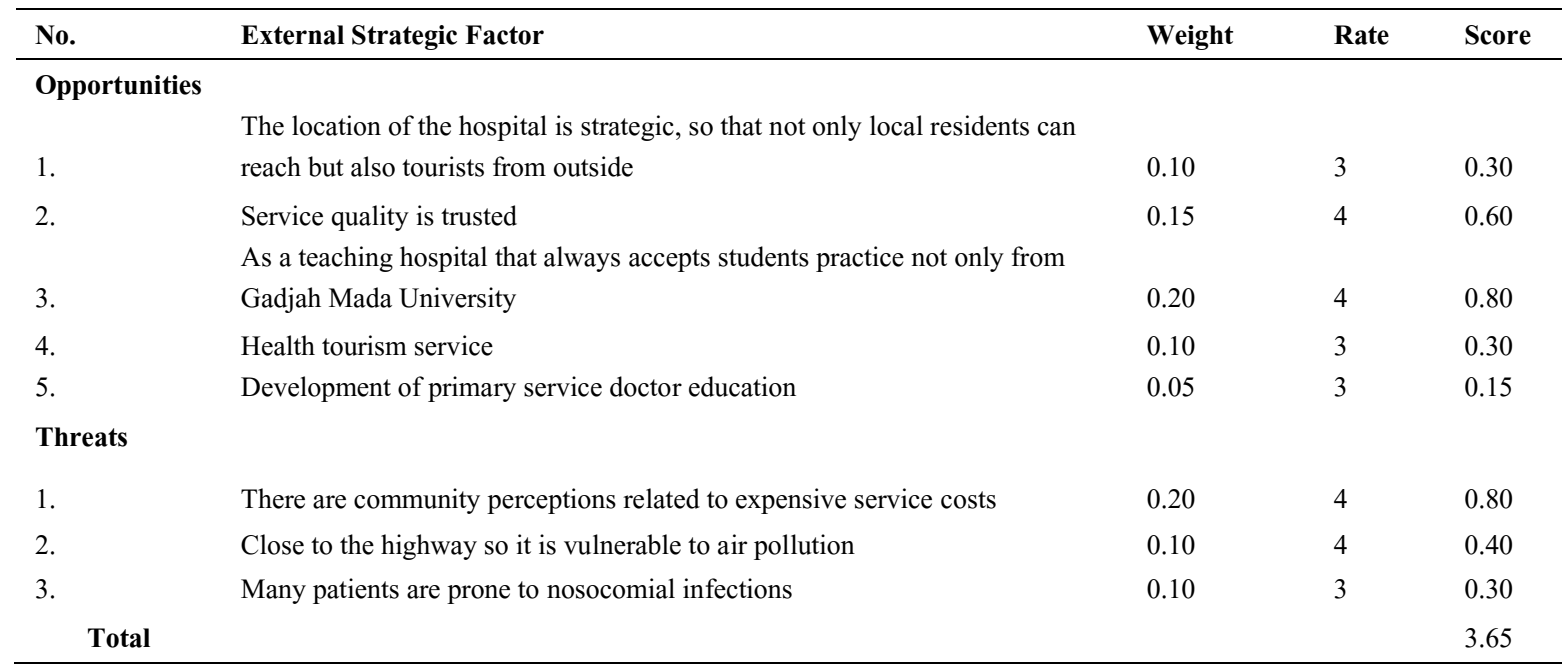

\section{CONCLUSION}

Obtained a total FSI score of 3.35 means greater strength than weakness, while the total FSE score of 3.65 means that the opportunity is greater than the threat. Therefore, the strategy used is SO (strength and opportunity). This strategy is carried out by developing and increasing strength and maintaining the opportunities available at Dr. Sardjito General Hospital.

\section{ACKNOWLEDGEMENT}

Thank you to my children who helped in taking this research data: Via, Triyani, Eka Nur, lilis H, Sely A, Defita, Faky. Thank you to the dean and vice dean of the Faculty of Public Health, University of Ahmad Dahlan who continue to provide support.

\section{REFERENCES}

1. Wibowo DH, Arifin Z, Sunarti S. Analisis Strategi Pemasaran untuk Meningkatkan Daya Saing UMKM (Studi pada Batik Diajeng Solo). J Adm Bisnis. 2015 Desember;29(1):59-66.

2. Stanton WJ. Fundamentals of Marketing. 5th ed. Tokyo: McGraw-Hill Book Company; 1978.

3. Ahmed R, Samreen H. Assessing the Service Quality of Some Selected Hospitals in Karachi Based on the Servqual Model. Pak Bus Rev. 2011 Jul;266-314.

4. Otani K, Herrmann PA, Kurz RS. Improving patient satisfaction in hospital care settings. Health Serv Manage Res. 2011 Nov;24(4):163-9.

5. Upadhyai R, Jain AK, Roy H, Pant V. A Review of Healthcare Service Quality Dimensions and their 
Measurement. J Health Manag. 2019 Mar;21(1):10227.

6. Ahmad A, Al-Qarni A, Alsharqi O, Qalai D, Kadi N. The Impact of Marketing Mix Strategy on Hospitals Performance Measured by Patient Satisfaction: An Empirical Investigation on Jeddah Private Sector Hospital Senior Managers Perspective. Int J Mark Stud. 2013 Nov 13;5(6):210-27.

7. Rosalia KJ, Purnawati NK. Pengaruh Kualitas Pelayanan terhadap Kepuasan Pasien RSU Surya Husadha di Denpasar. E-J Manaj Unud. 2018;7(5):2442-69.

8. Rensiner R, Azwar VY, Putra AS. Analisis Faktor Kualitas Pelayanan terhadap Kepuasan Pasien Rawat Jalan RSUD Dr. Achmad Darwis. J Kesehat Andalas. 2018;7(2):1-8.

9. Yulyuswarni Y. Mutu Pelayanan Farmasi Untuk Kepuasan Pasien Rawat Jalan di Instalasi Farmasi Rumah Sakit Swasta. J Ilm Keperawatan Sai Betik. 2017 Jan 26;10(1):110-5.

10. Rangkuti F. Analisis SWOT: Teknik Membedah Kasus Bisnis. 22nd ed. Jakarta: PT. Gramedia Pustaka Utama; 2015.

11. Badan Perencanaan Pembangunan Nasional. Rencana Pembangunan Jangka Menengah Nasional (RPJMN) 2015-2019. Jakarta; 2014.

12. Sekaran U. Metodologi Penelitian untuk Bisnis. 4th ed. Jakarta: Salemba Empat; 2006.

13. Otani K, Waterman B, Dunagan WC. Patient Satisfaction: How Patient Health Conditions Influence Their Satisfaction. J Healthc Manag Am Coll Healthc Exec. 2012 Aug;57(4):276-292; discussion 292-293.

14. Badjamal FA. Pengaruh Kompotensi dan Fasilitas terhadap Kepuasaan Pasien Rawat Inap Kelas 3 pada RSUD Palu. E-J Kat. 2014 Jul;2(1):200-10.

15. Safitri DN, Hidayat W, Dewi RS. Pengaruh Kualitas Pelayanan, Lokasi, dan Tarif Terhadap Kepuasan Pasien Rawat Inap Rumah Sakit Lestari Raharja Kota Magelang (Studi Kasus pada Pasien Rawat Inap Non Asuransi). J Ilmu Adm Bisnis. 2015 Apr;4(2).

16. Fadilah AN, Hakim A, Siswidiyanto S. Pengaruh Penempatan Pegawai terhadap Kinerja (Studi pada Pegawai Sekretariat Daerah Kabupaten Gresik). J Adm Publik. 2013;1(5):847-52.
17. Tjiptono F. Manajemen Jasa. Yogyakarta: Penerbit Andi; 2007.

18. Haryanto JO, Ollivia O. Pengaruh Faktor Pelayanan Rumah Sakit, Tenaga Medis, dan Kualitas Pelayanan Rumah Sakit Terhadap Intensi Pasien Indonesia Untuk Berobat di Singapura. J Ekon Bisnis. 2009 Agustus;2(14):144-51.

19. Kusuma EW, Suryoko S, Budiatmo A. Pengaruh Tarif dan Kualitas Pelayanan terhadap Kepuasan Pasien Rawat Inap di RSUD RAA Soewondo Pati. $J$ Ilmu Adm Bisnis. 2014 Oktober;3(4).

20. Purnomo SH, Zulkieflimansyah. Manajemen Strategi: Sebuah Konsep Pengantar. Depok: Lembaga Penerbit FE-UI; 2009. 